\title{
WATER QUALITY INDICATOR BACTERIA IN BENGAWAN SOLO AND PORONG RIVERS AND THEIR ESTUARIES *)
}

\author{
by \\ Soeminarti S. Thayib; Ruyitno;Djoko Hadi KunARSo and \\ HAMIDAH RAZAK ${ }^{* *}$ )
}

\begin{abstract}
Water samples taken from rivers and estuaries stations in Bengawan Solo and Porong rivers in East Java were analyzed for the pollution of indicator bacteria in July-August and NovemberDecember 1984, to determine the influences of domestic wastes on the quality of these waters. Higher frequency of occurrences of high total coliform, fecal coli and fecal streptococci were observed in water samples collected in river stations, river mouths and in the vicinity of dense populated areas. The distribution of saprophytes, freshwater bacteria and indicator bacteria were also studied. The changes in the bacterial population as funciton of the salinity were shown during the observations. Some pathogenic bacteria like Salmonella, Yarsinia, and Vibrio parahaemolyticus and others have been isolated from waste and mud samples.
\end{abstract}

\section{INTRODUCTION}

Bengawan Solo and Porong rivers are located in East Java. One of them pours its water to the northern coast and the other to the northeastern coast of Java. Both rivers belong to the ten longest and biggest rivers in Java. Local people uses the water directly for daily needs. People living in the coastal parts of that area utilize the richness of the waters also for other purposes like transportation and recreation.

Since sewage system in the country is not sufficient, all domestic wastes are directly dumped into the sea, therefore degradation of coastal waters could happen very rapidly. The pollutant will increase nutrient load in the sea, which could act as protection against effects of salinity and temperature resulting in the survival of bacterial strains that would otherwise die off (CARNEY et al, 1975), including the pathogenics.

The domestic wastes create more problems and more difficult to manage compared to industrial wastes, since it deals with low income strata of the population. So far, indicator bacteria which is mostly used to asses the degree of bacterial pollution, have not received proper attention and interest from Indonesian research workers.Realizing the importance of the sea for an archipelagic country like Indonesia

*) Paper presented in the International Symposium on the Results of Snellius II Expedition, Jakarta Indonesia, 22-28 November 1987.

**) Centre for Oceanological Research and Development, Indonesian Institute of Sciences. 


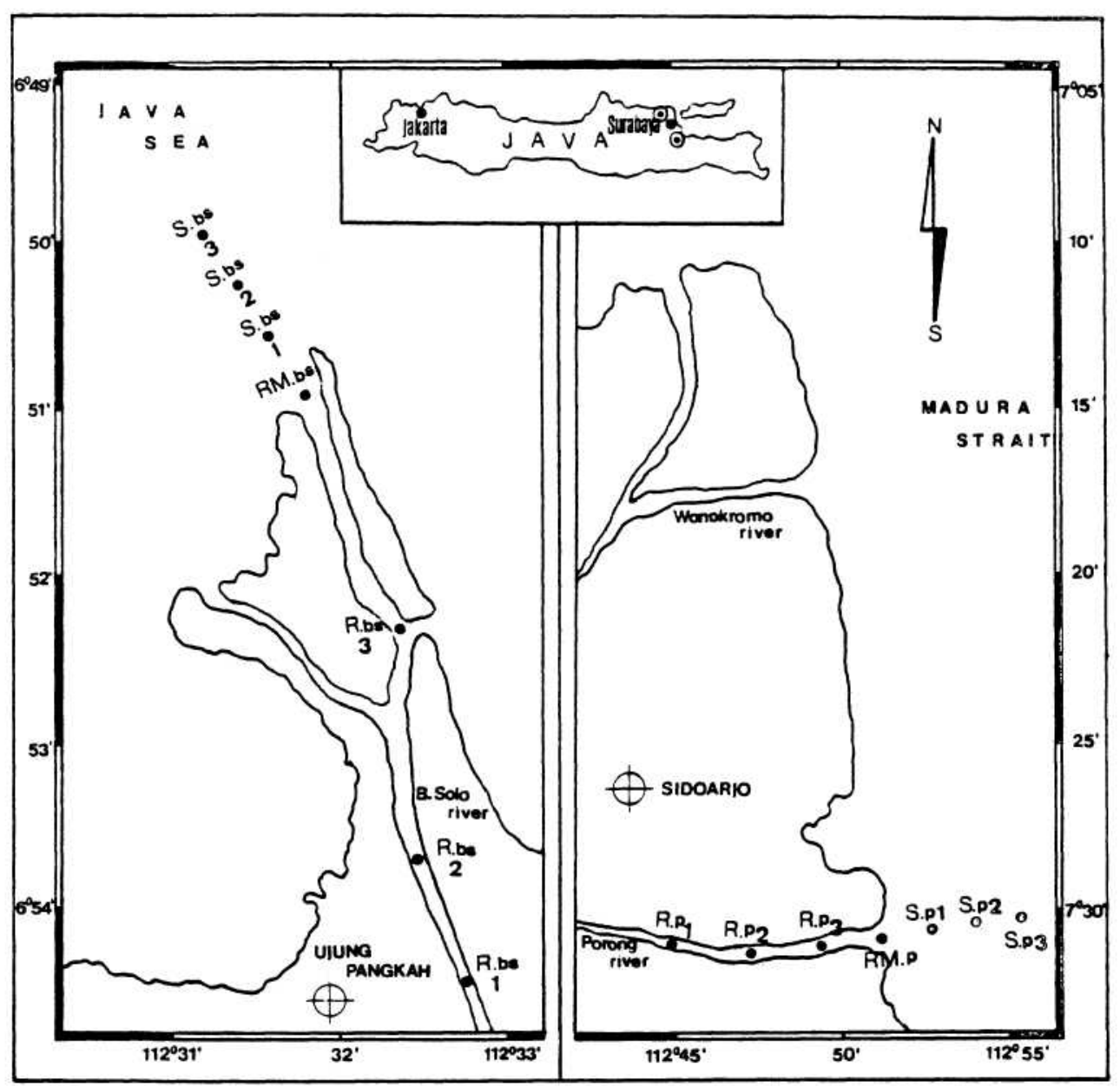

Figure 1. Sampling sites in Bengawan Solo and Porong rivers. 
All aspects of marine research in general, in particular those dealing with pollution, ought to receive more attention.

The objective of this study is to obtain a bacteriological evaluation of the Solo and Porong rivers and estuaries as part of the coming larger study on the impact of river inputs on the ecology of the microorganisms in estuarine waters.

\section{MATERIALS AND METHODS}

Surface water samples from the depth of $1 \mathrm{~m}$ were taken from stations located in the river (Rl, R2, R3) in the river mouth (RM) and from the sea (SI, S2, S3) (Fig. 1). Samples were taken during dry (June-July 1984) and wet (December 1984) seasons. The microbiological parameters measured were total plate count of saprophytes, and freshwater bacteria (RHEINHEIMER, 1970). Number of coliform, fecal coli and fecal streptococci were determined by using membrane filter method. Pathogenic bacteria were isolated based on the method recommended by World Health Organization (1977). Total organic carbon, salinity and seston were also analysed during the observations.

\section{RESULTS AND DISCUSSION}

\section{Saprophytes and freshwater bacteria}

Differences in composition and amount of microbial population found in estuaries and river mouths area are due to the variety and nature of waste materials and microorganisms carried by streams. There are at least two ecological group of microorganisms occurred in Bengawan Solo estuarine waters : the saprophytes and the fresh water bacteria.

Generally the saprophytes (SWA) counts fluctuated from time to time and from place to place. Salinity, organic nutrient, tides, seston and season could influence amount of saprophytes and freshwater (FWA) bacteria.

KusNezov (1950, cited by RHEINHEIMER 1980) stated that high saprophytes numbers indicate intensive decomposition of organic material. The presence of aerobic heterotrophic (saprophytic) bacteria could be used as a guide to the level of organic matter in water.

Figure 2 presents the results obtained during observations in the dry and wet seasons in the river and estuary of Bengawan Solo. The saprophytes varied from $25 \times 10^{3}$ to $250 \times 10^{3}$ to $250 \times 10^{3}$, the freshwater bacteria from $23 \times 10^{3}$ to $220 \times 10^{3}$. Higher count of saprophytes were obtanined from sea station (S3) and river mouth (RM) and the higher counts of freshwater bacteria in river stations $\mathrm{Rl}$ and R2. Results from the wet season showed that the bacterial count figures are lower than those of the dry season. Results of surveys in the Bay of Jakarta 1978-1983 (P3O-LIPI, unpublished) showed that after a lapse of about one month preceding the wet season the 

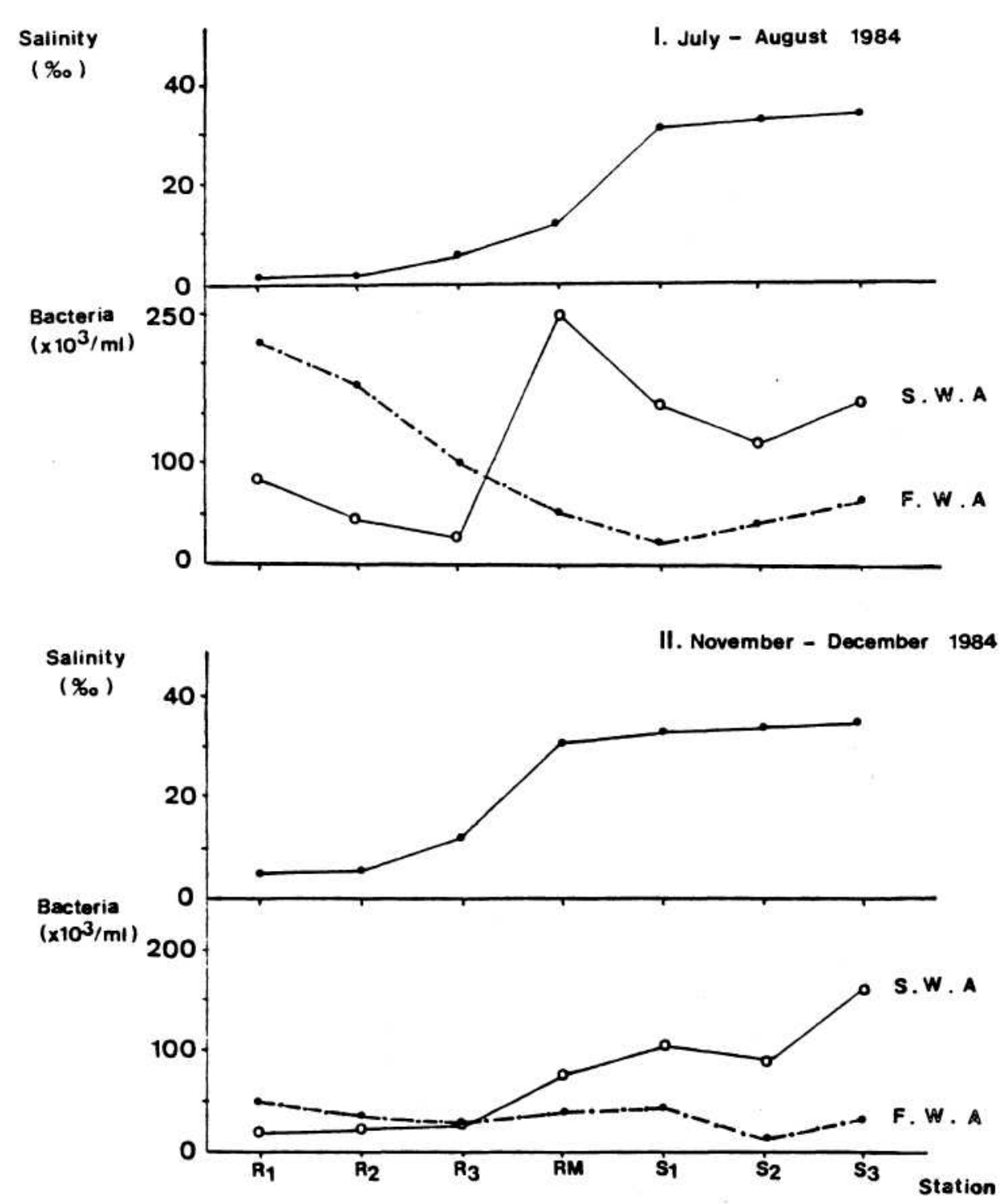

Figure 2. Distribution of salinity, saprophytes and freshwater bacteria throughout river stations extended to sea stations in July - August 1984 (I) and November - December 1984 (II) in Bengawan Solo.

S.W.A. : Saprophytic bacteria

F.W.A. : Fresh water bacteria

$\mathrm{R}$ : River station

RM : River mouth station

$\mathrm{S}$ : Sea station 
Water Quality Indicator Bacteria in Bengawan Solo
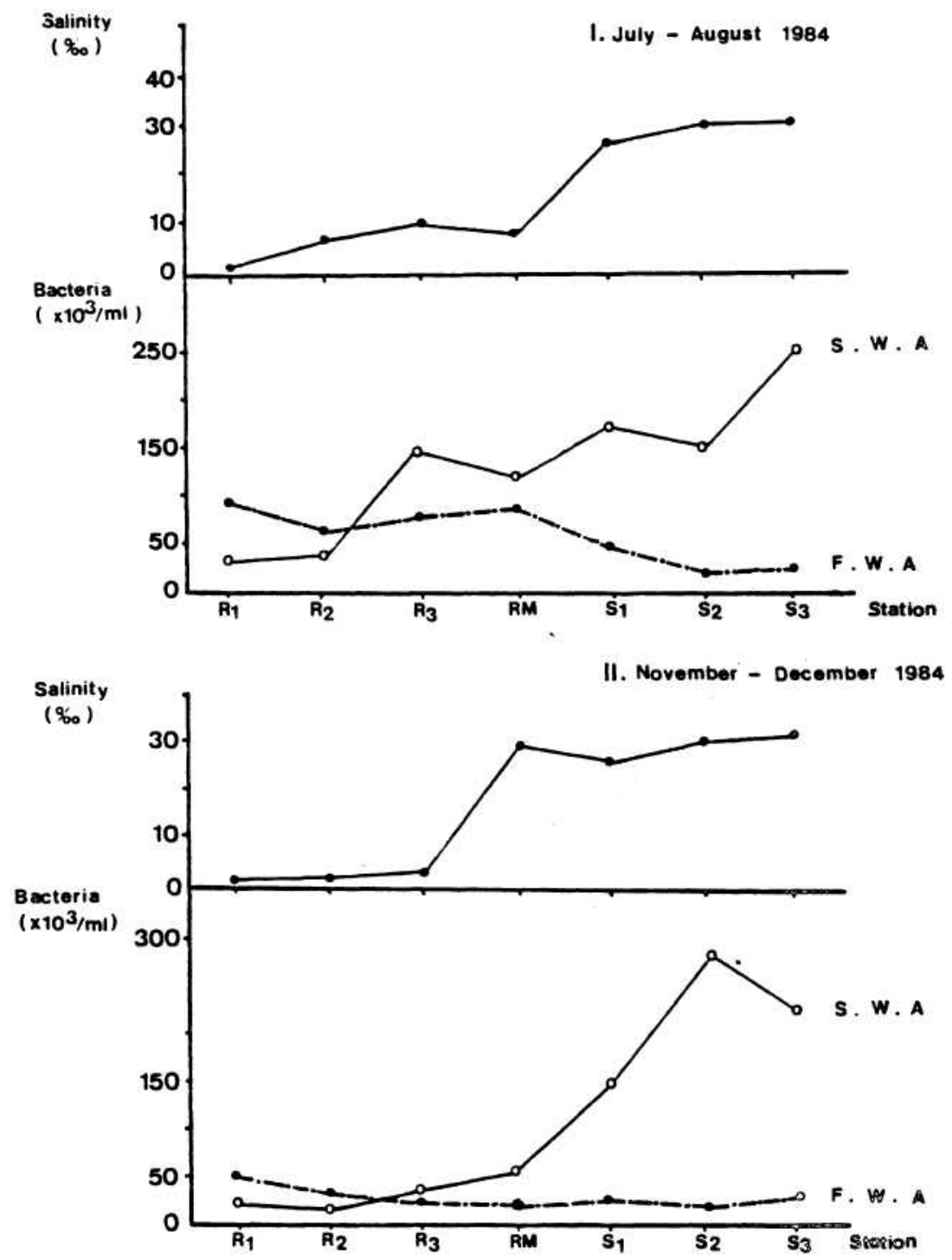

Figure 3. Distribution of salinity, saprophytes and freshwater bacteria throughout river stations extended to sea stations in July - August 1984 (I) and November-December 1984(II) in Porong reiver.

S.W.A. : Saprophytic bacteria

F.W.A. : Fresh water bacteria

$\mathrm{R}$ : River station

RM : River mouth station

Se : Sea station 


\section{S. S. THAYiB et al.}

heterotrophic tends to increase markedly.

In general, the saprophytes (SWA) changes as a function of salinity. The saprophytes tend to increase with increasing salinity, except for station R3. In that station, the bacterial population seems to suffer a stress. This condition appeared in both seasons and is valid for the indicator bacteria as well and was probably due to the changes of organic matter. The total organic matter in this station dropped markedly from $500 \mathrm{ppm}$ in station R2 to $50 \mathrm{ppm}$ in station R3.

In Porong River stations, the counts of the freshwater (FWA) bacteria is higher than in sea stations. The amount of fresh bacteria is in the opposite condition to the saprophytes. It increased in number with the decrease of salinity (Fig.3).

Figure 3 presents the distribution of the saprophytes and the freshwater bacteria, from river stations Rl, R2, R3 and RM extending to sea stations (SI, S2 and S3) in dry and wet seasons. The saprophytes changes as a function of salinity. It increased with increasing salinity. Slight fluctuations occurred. The saprophytes counts varied from $19 \times 10^{3}$ per $\mathrm{ml}$ to $286 \times 10^{3}$ per $\mathrm{ml}$ and the freshwater bacteria from $21 \times 10^{3}$ per $\mathrm{ml}$ to $102 \times 10^{3}$ per ml. Higher counts of saprophytes were recorded during the dry season. Sea stations in general have more counts than river stations. The rises of saprophytes count in the wet season in stations S2 was recorded. One of the several factors which may influence the increase of saprophytes is the increase of total organic carbon which have been recorded during the survey. The canges of freshwater bacteria (FWA) from river stations to the sea stations could be noticed in Figure 3. In general higher counts of freshwater bacteria were obtained from river stations. There were slight fluctuations from station to station. The freshwater bacteria varied from $21 \times 10^{3}$ per $\mathrm{ml}$ to $90 \times 10^{3}$ per ml. Results from dry season observation shows higher counts than those from wet season. The same results were also recorded during observations in Bengawan Solo. The dilution of the water in rivers and estuaries in rainy season might became the reason of these condition.

\section{Indicator bacteria}

Accounting of the fact that sewage system in Indonesia is still far from developed, the amount of indicator bacteria in the sea tends to increase. Domestic waste from human settlements are directly or indirectly disposed into the rivers and the sea becomes waste repository. The sewage effluents from household not only will add nutrients permitting growth, but also increase the amounts of indicator bacteria and pathogenic bacteria.

The distribution of indicator bacteria changes in population with salinity in Bengawan Sol is presented in Figure 4. The distribution of salinity is presented in Figure 2.

In general, higher counts of indicator bacteria were obtained from river stations ( $\mathrm{Rl}$ and $\mathrm{R} 2$ ) which have salinity between $0.4-6 \%$. This was shown during the dry or the wet season and probably due to an additional input of sewage through a canal which has a connection with the stations.

Results of dry season observation showed that the counts of fecal coli varied from 40 to 190 per $100 \mathrm{ml}$, coliform 72 to 248 per $100 \mathrm{ml}$, and fecal 
Water Quality Indicator Bacteria in Bengawan Solo

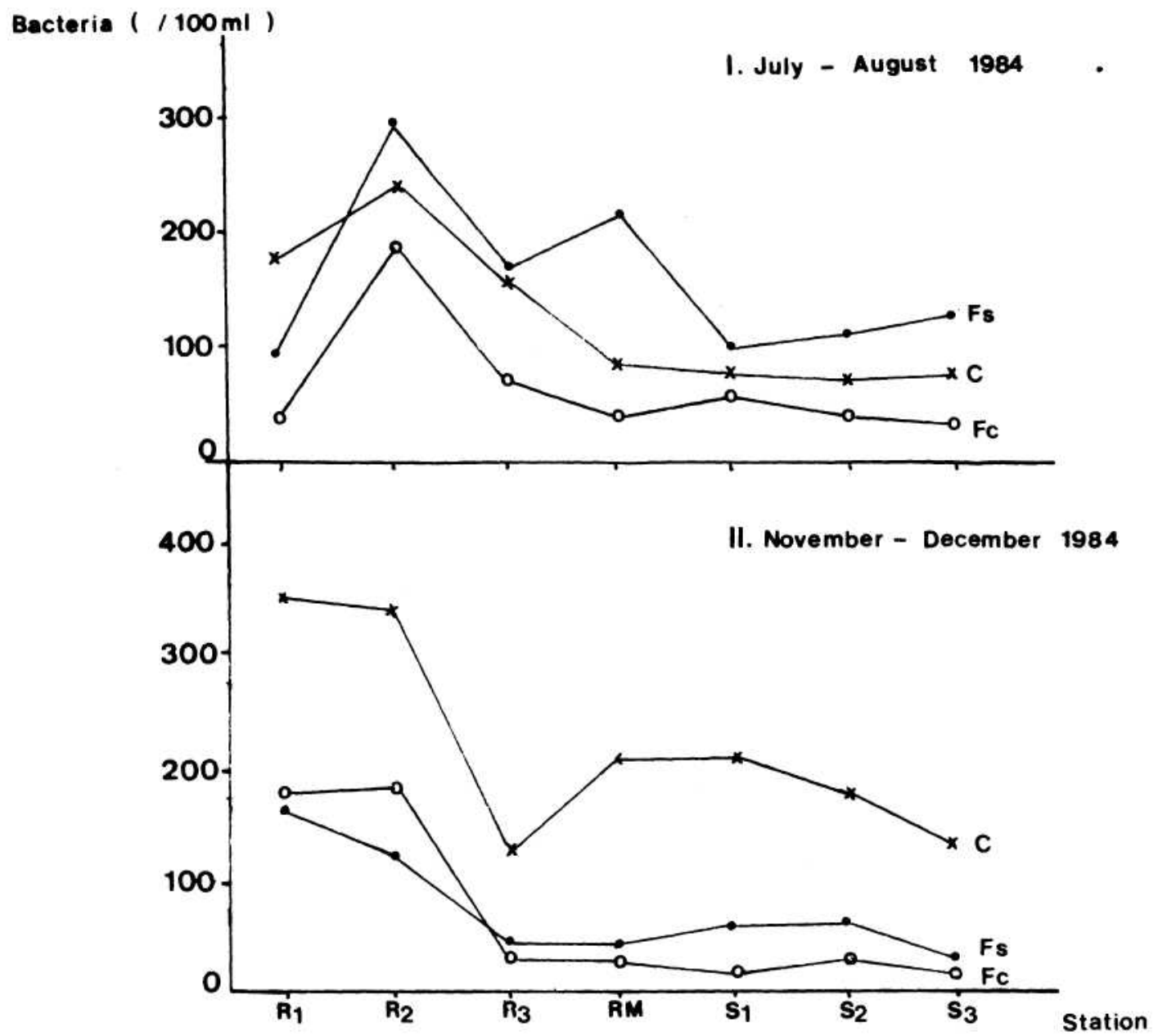

Figure 4. Indicator bacteria in Bengawan Solo in July - August 1984 (I) and November - December 1984 (II)

C : Coliform bacteria

Fc: Fecal coli bacteria

Fs : Fecal streptococci bacteria 


\section{S. S. THAYіB et al.}

streptococci from 104 to 300 per $100 \mathrm{ml}$. In the wet season, fecal coliform had lower counts which were between 5 and 170 per $100 \mathrm{ml}$. Coliform counts were higher in comparison to those of the dry season, it varied from 40 to 340 per $100 \mathrm{ml}$. Fecal streptococci were between 7 and 170 per $100 \mathrm{ml}$.

Generally, the patterns of the distribution of indicator bacteria throughout river stations extended to the sea station (Fig. 4) was demonstrated markedly showing bacteria changes as a function of salinity. The indicator bacteria decreased with increasing salinity. The survival for most pathogenic bacteria is greater in freshwater lakes and rivers than in the sea, since sea water is bactericidal for non marine bacteria (RHeinheimer, 1980). Mitchell (1972 . as cited by RHEINHEIMER 1980), explained that in inland waters and also in the sea, an inversely proportional connection seems to exist between to bacterial population present in the water. Results of this experiments showed that the survival time of Escherichia coli decreases with increasing numbers of added marine bacteria. Only slight difference in amount of indicator bacteria were demonstrated between the dry and wet season observations.

Generally, the distribution pattern of indicator bacteria throught river stations extended to the sea station. Figure 2 described marked by that the amount of indicator bacteria changes as a function of salinity. The indicator bacteria decrease with increasing salinity. The survival for most pathogenic bacteria is greater in freshwater lakes and rivers than in the sea, as seawater is bactericidal for non marine bacteria (RHeinheimer 1980). Mitchell (1972 as cited by RHeinheimer 1980) explained that in inland waters and also in the sea, an inversely proportional connection seems to exist between the bacterial populations present in the water. Results of Escherichia coli decreased with increasing numbers of added marine bacteria.

Only slight differences in the amount of indicator bacteria were demonstrated between the dry and wet season observations. The amount of fecal coli showed high counts in R2 and dropped markedly in station R3. It occurred both in the dry and wet seasons. Results of the dry season showed that the indicator bacteria fluctuated from station to station and then tended to increase slightly in sea stations during dry season and decrease during the wet season. It seems that there is a connection between the total organic matter and the amount of indicator bacteria. The results of the observation showed that the content of total organic carbon was low in the station Rl increased distinctly in R2, decreased markedly in R3 and rose in RM, rose very highly in S. Very small differences in total organic matter was demonstrated along the sea stations. There was no marked difference between the distribution pattern of indicator bacteria compared to that of total organic carbon.

In dry season, station S3 could be considered as the relatively more polluted station than S2, while the opposite condition occurred in the wet season, the indicator bacteria tended to decrease from station S2 to S3 (Fig. 4).

All indications counts obtained were still below the Indonesian Standard and WHO Standard applied for recreation and aquaculture which is 1000 of fecal coli per $100 \mathrm{ml}$ (for Indonesian Standard). The same figure is also recommended by WHO 1970 for recreation. 
Water Quality Indicator Bacteria in Bengawan Solo

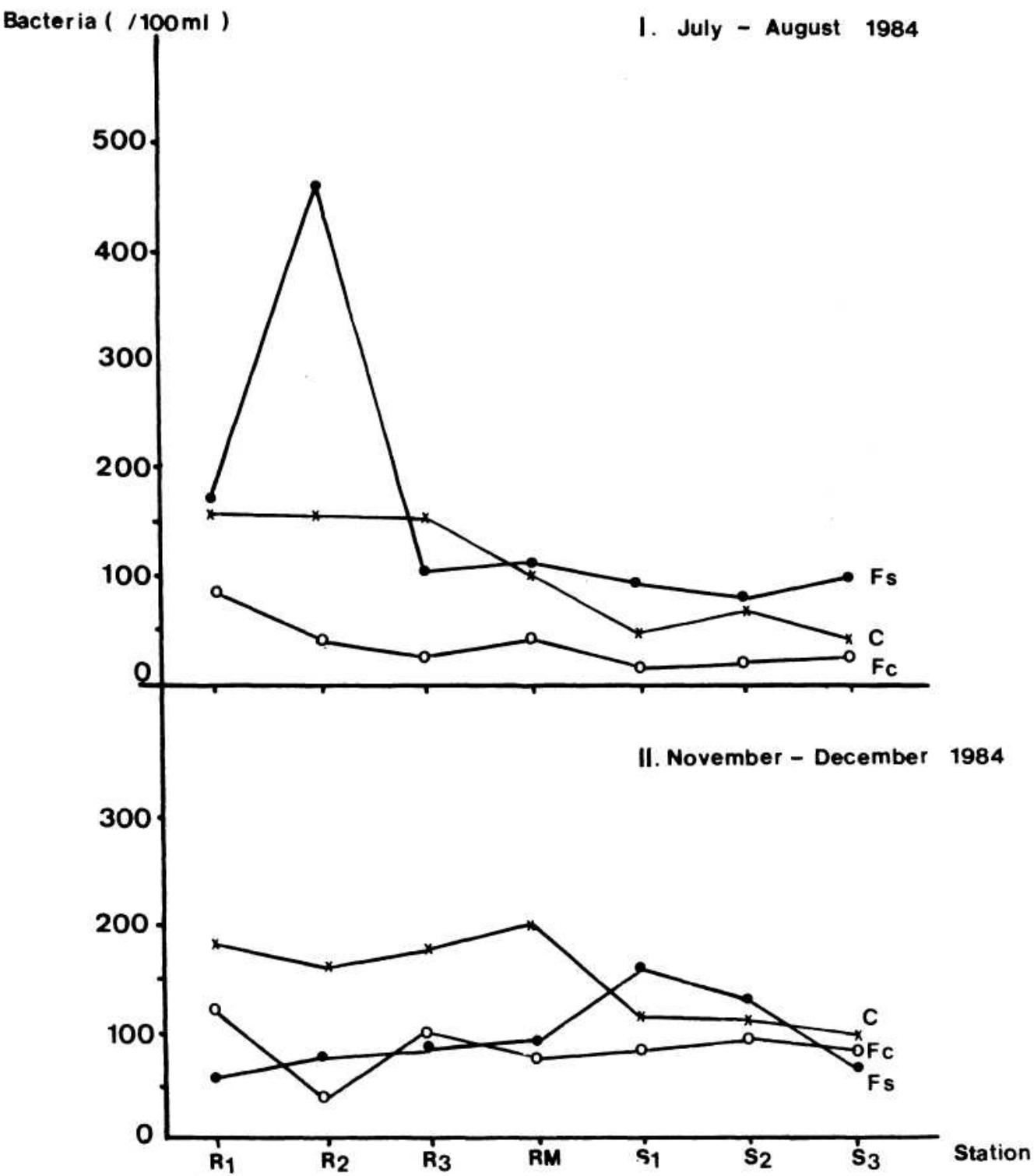

Figure 5. Indicator bacteria in Porong river in July - August 1984 (I) and November - December 1984 (II).

C : Coliform bacteria

Fc : Fecal coli bacteria

Fs : Fecal streptococci bacteria 
S. S. THAYiB et al.

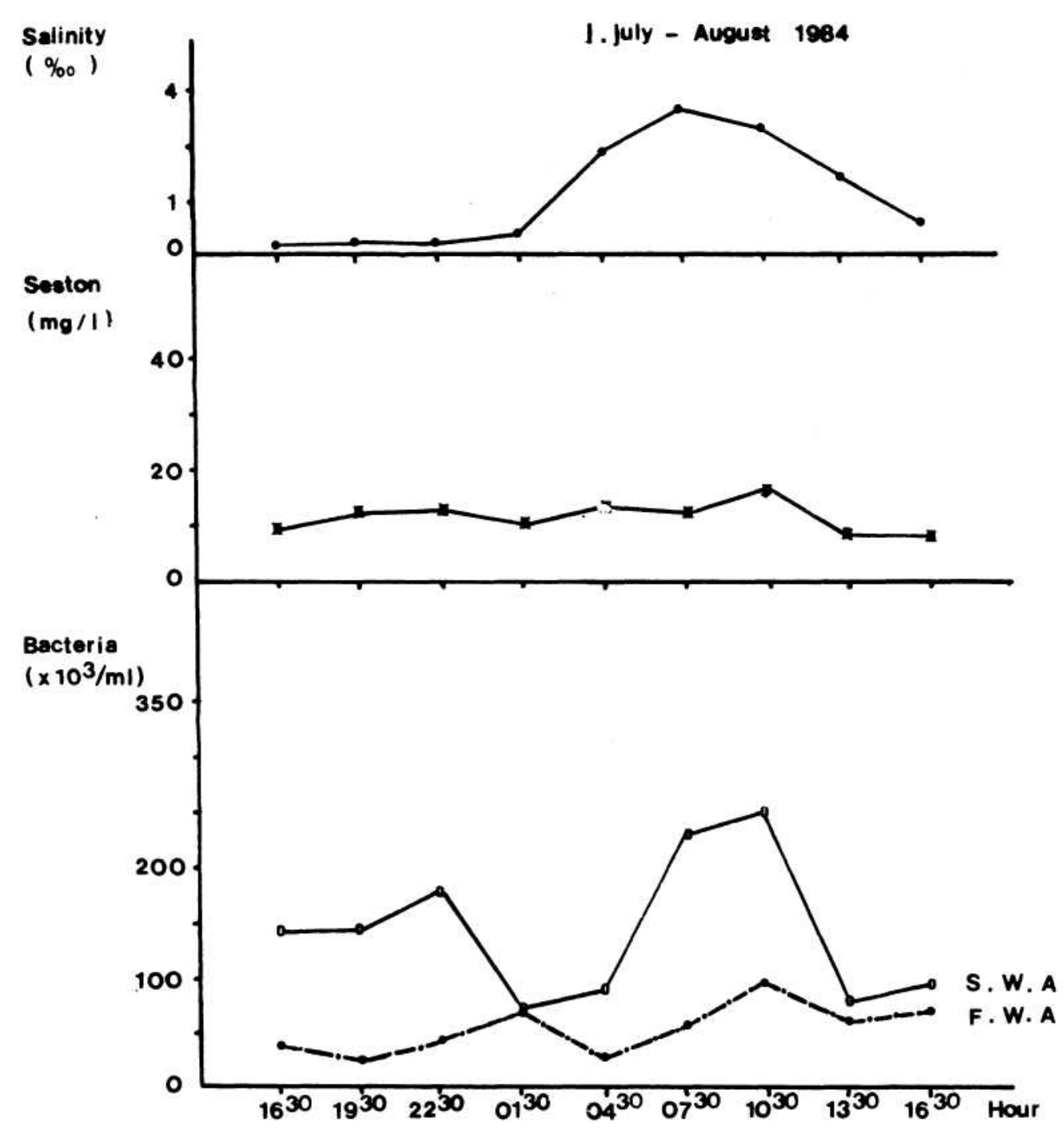

Figure 6. Changes of salinity, seston and bacteria population during 24 hours observations in July - August 1984 (I) in Bengawan Solo.

S.W.A. : Saprophytic bacteria

F.W.A. : Fresh water bacteria. 
Water Quality Indicator Bacteria in Bengawan Solo

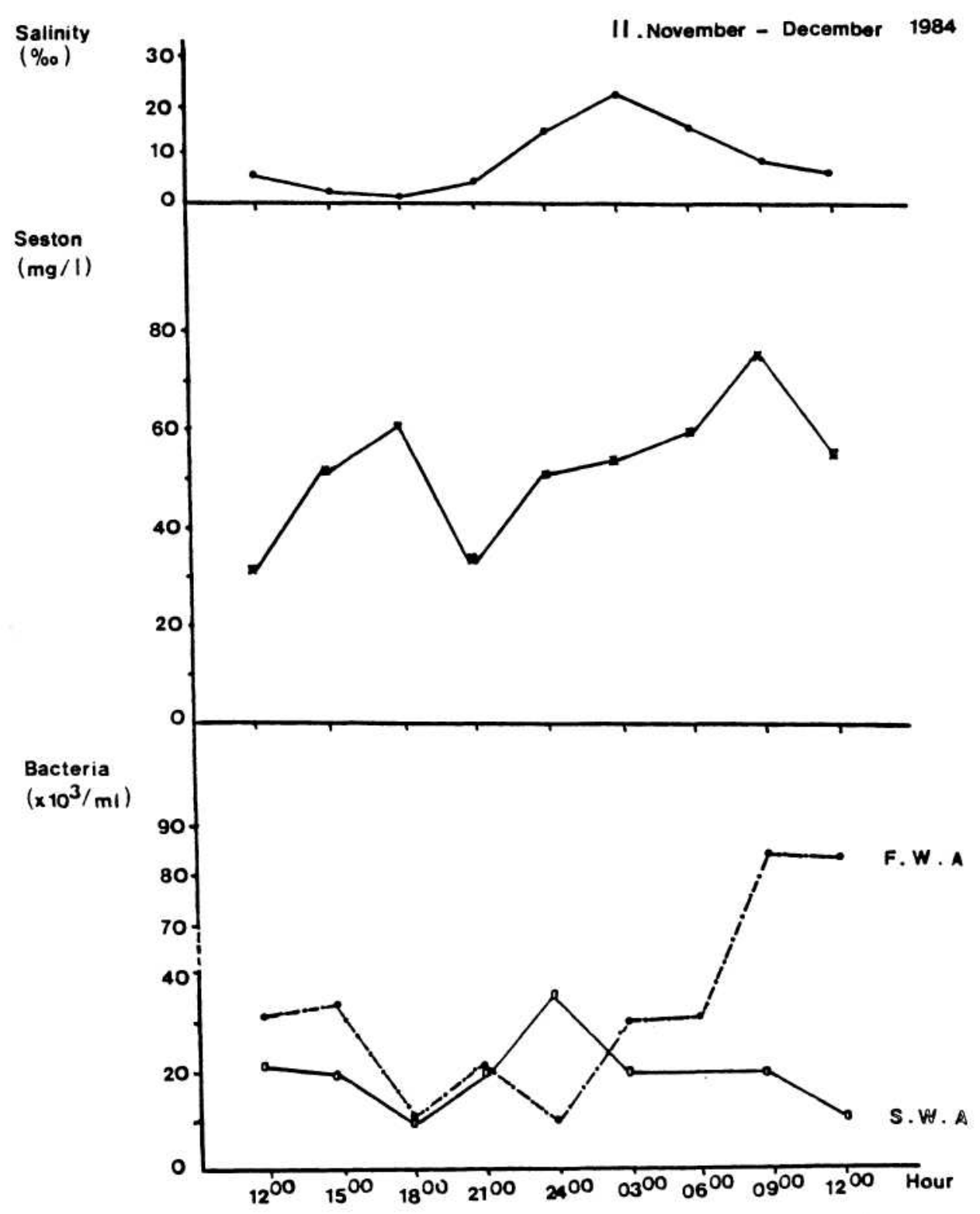

Figure 7. Changes of salinity, seston and bacteria population during 24 hours observations in November - December 1984 (II) in Bengawan Solo.

S.W .A. : Saprophytic bacteria

F.W.A : Fresh water bacteria 


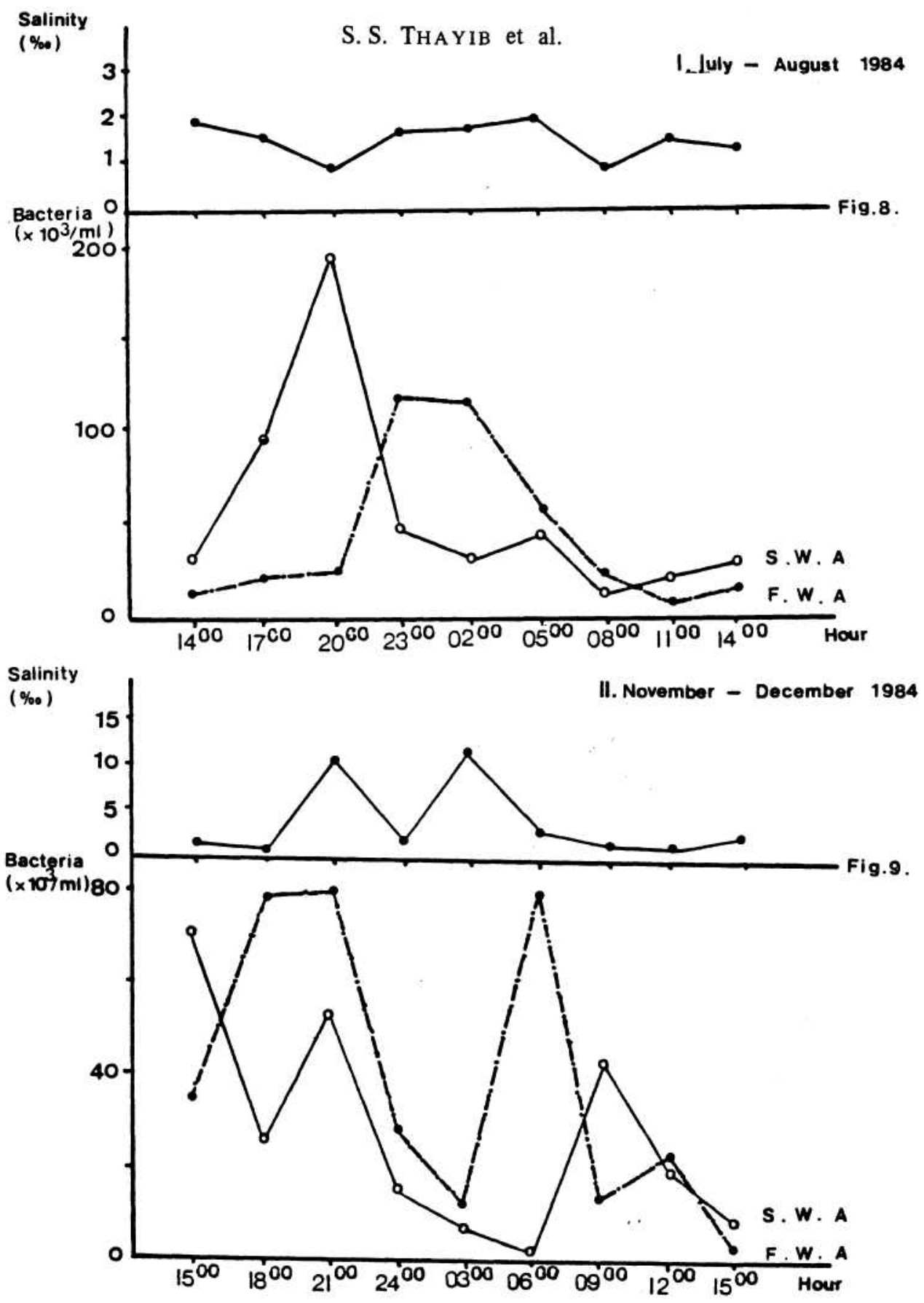

Figure 8 and 9. Changers of salinity and bacteria population during 24 hours observations in July — August 1984(1) and November — December 1984 (II) in Porong river.

S.W.A. : Saprophytic bacteria

F.W.A. : Fresh water bacteria 
During the dry season fecal streptococci occur in larger amount in nearly all station, except for freshwater stations which were located in the river (Rl). Fecal streptococci have relatively better surviving ability in saline water then fecal and coliform bacteria.

Figure 5 presents the distribution of indicator bacteria and changes in bacterial indicator population with salinity in Porong River. Higher counts of indicator bacteria were obtained from river stations (R1-R2). This was shown in dry and wet seasons observations. Higher fecal streptococci were sometimes recorded in sea stations, where lower counts of fecal coli and coliform occurred. The same condition often recorded from other works, e.g. observations during survey in Bengawan Solo and in Cilacap waters (southern part of Central Java) (THAYIB 1987 unplublished). If the resistance to salinity is a prominent characteristic of enterococci, then it would be more suitable if enterococci is used as indicator for the quality of estuarine waters rather than fecal coli and coliform. The fecal coli varied from 2 to 160 per $100 \mathrm{ml}$, the coliform from 42 to 200 per $100 \mathrm{ml}$, and fecal streptococci from 80 to 470 per $100 \mathrm{ml}$. Figures 6, 7, 8 and 9, present data obtained from 24-hour observations in the mixing zone of Bengawan Solo and Porong rivers Higher counts of saprophytes were found in samples with higher content of seston and higher salinity. THAYIB \& SUHADI (1977) revealed that there is a significant correlation between seston and saprophytes showed during their bacteriological studies in the Bay of Jakarta. During high tide the increase of salinity was followed by the increase of the saprophytes (Figs. 6 and 7). Slight fluctuations occurred in the amount of saprophytes due to the changes in concentration of seston. The fluctuation of freshwater bacteria tend to be more closely related to salinity rather than to concentration of seston as it was recorded during the wet season observations in Bengawan Solo estuary (Figs. 6 and 7). Figures 10 and 11 show the results of 24 hours observations of indicator bacteria in Bengawan Solo and Porong rivers mixing zone. The amount of fecal indicator bacteria fluctuated in 24 hours but they are still beneath the standard laid by the government of Indonesia proposed for aquaculture and recreation. The fecal streptococci tended to increase in high tide. The relation between the tides and other two groups of indicator bacteria were not markedly observed. The comparison of water quality indicator bacteria of Bengawan Solo and Porong rivers and estuaries are presented in Figure 11. The investigation conducted in dry season showed that the Bengawan Solo river and estuary had relatively worse quality than Porong river. The river mouth and the sea stations of Bengawan Solo was in better condition during wet season, but Salmonella was isolated also in the wet season. Based on these findings, it could be revealed that pathogenic bacteria data is important to be applied for water quality evaluation beside indicator bacteria.

\section{Pathogenic bacteria}

Certain kinds of pathogenic bacteria were isolated from Bengawan Solo and Porong rivers.They are associated to water and mud. Salmonella was isolated from mud samples. Thestudy of BUtTIAUX and LEURS (1953as quoted by GRUNNET 


\section{S. S. THAYiB et al.}

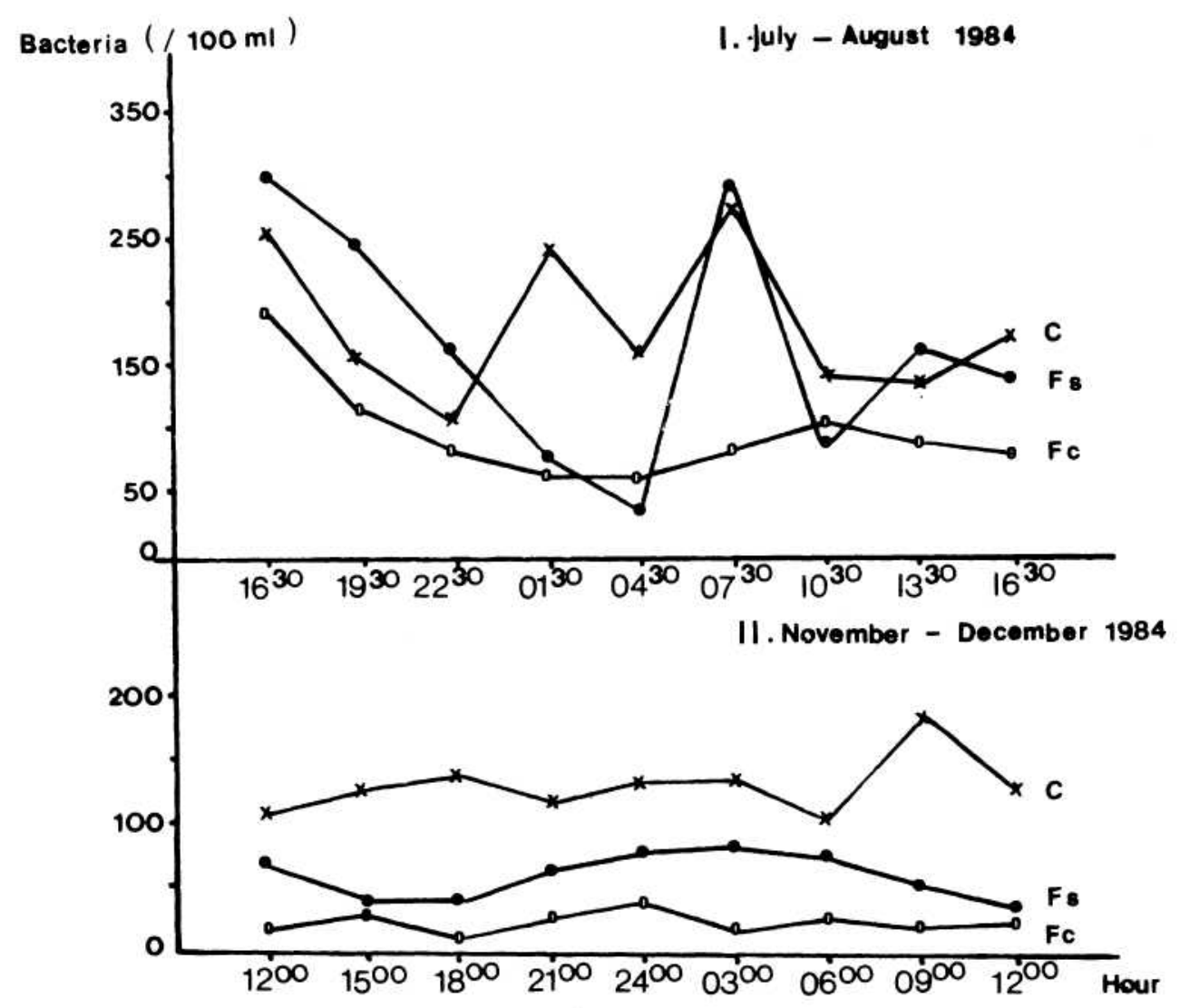

Figure 10. Indicator bacteria during 24 hours observations in Bengawan Solo in July - August 1984 (I) and November - December 1984 (II).

C : Coliform bacteria

Fc : Fecal coli bacteria

Fs : Fecal streptococcus bacteria 
Water Quality Indicator Bacteria in Bengawan Solo

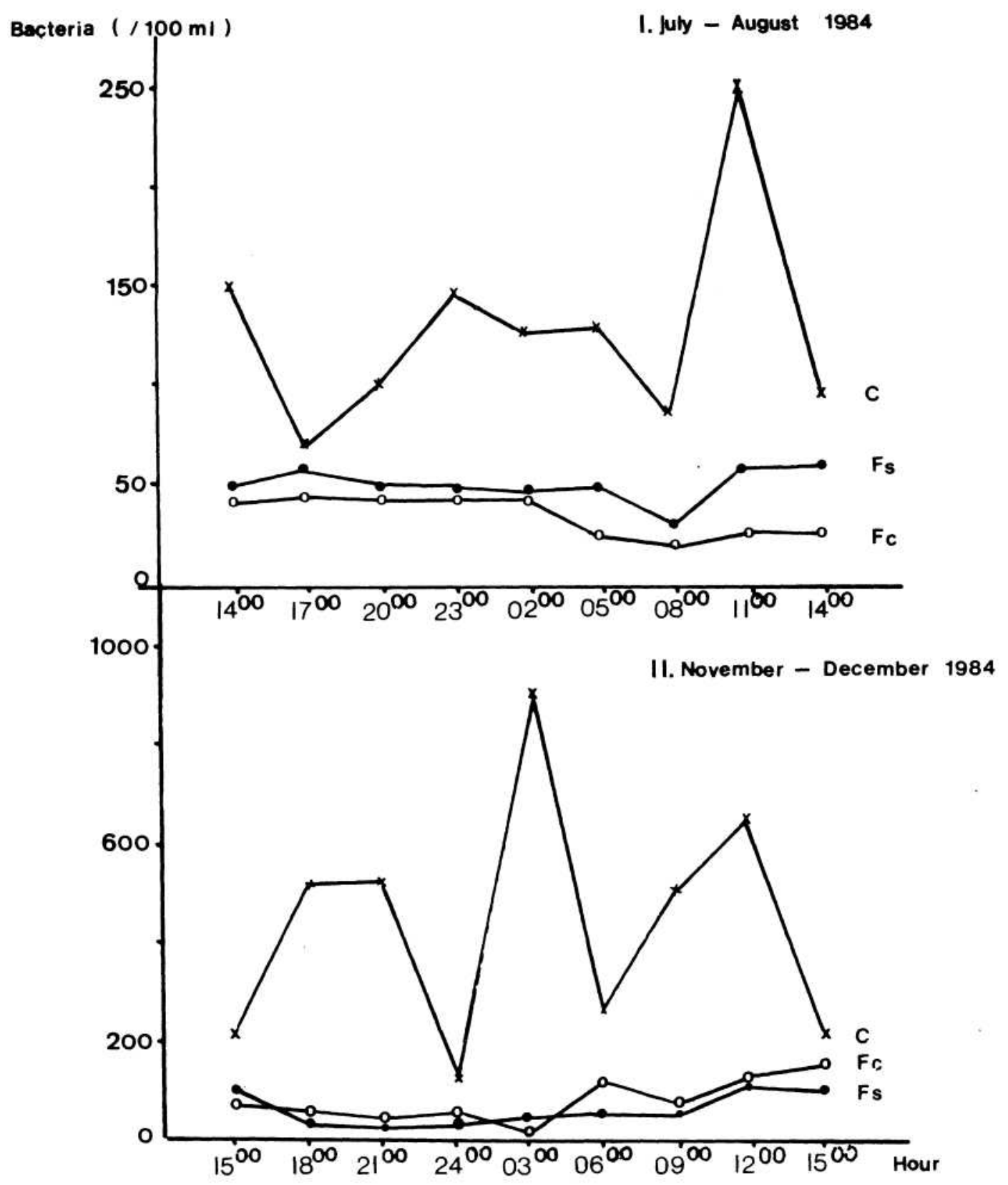

Figure 11. Indicator bacteria during 24 hours observations in Porong river in Juiy August 1984 (I) and November - December 1984 (II).

C : Caliform bacteria

Fc: Fecal coli bacteria

Fs: Fecal streptococcus bacteria 


\section{S. S. THAYIB et al.}

1975) stated that Salmonella types in freshwater have shown a marked fall in number of organisms in the course of 48 hours. In sea water, however, counts of Salmonella paratyphi and S. enteritidis are practically unchanged where as S.typhi after an initial decrease lasting for about 11 hours increased in number. Hence, it was not surprising that Salmonella could be found in marine environment with low numbers of indicator bacteria in Bengawan Solo. An opposite condition had been found in the result from surveys conducted in the Bay of Jakarta and in Strait of Bangka (THAYIB and SUHADI 1980). The result of those investigations showed that there is relationship between Salmonella isolation frequencies and the higher MPN fecal coli count of the environment.

The occurrence of pathogenic microbial species could raised serious public health problems. An infected human with acute salmonellosis excretes Salmonella in quantities of $10^{8}-10^{10}$ per gram faeces and excretion after continues for months or even years (GRUNNET 1975). Waterborne diseases outbreaks frequently occurred in coastal water where sanitation have been neglected. The pathogenic bacteria could be transmitted by direct contact with the environment or through intake of contaminated food. The presence of Salmonella in the sea product had been observed several times in the Bay of Jakarta (THAYIB and SUHADI 1980). The pathogenic halophilic obvious could be isolated from Bengawan Solo estuarine (Table 1). CABELLI (1978) explained that Vibrio parahaemolyticus could be used as an indicator of nutrient pollution. Some pathogenic bacteria like Yersiania, Vibrio parahaemolyticus, Pseudomonas aeroginosa and others could be isolated from water and mud samples (Table I). Data recorded from Bengawan Solo and Porong rivers revealed that the waters of these estuaries and rivers are already polluted although it was not clearly expressed in the water quality evaluated based on measurements with indicator bacteria like Coliform, fecal coli and fecal streptococci. Although lower indicator bacteria were recorded during the observations, the estuaries and the rivers of Bengawan solo and Porong may still have some pathogenic bacteria.

Tabel I. Positive results of pathogenic bacteria from water and mud samples.

\begin{tabular}{|l|c|c|c|c|c|c|c|c|c|}
\hline \multirow{2}{*}{} & \multicolumn{3}{|c|}{ Bengawan Solo } & \multicolumn{3}{c|}{ Por o n g } \\
\cline { 2 - 9 } & \multicolumn{3}{|c|}{ Mud } & \multicolumn{2}{|c|}{ Water } & \multicolumn{3}{c|}{ Mud } & \multicolumn{3}{c|}{ Water } \\
\cline { 2 - 9 } & I & II & I & II & I & II & I & II \\
\hline Salmonella & - & + & - & - & - & - & - & - \\
Vibrio angguilarum & - & + & - & - & - & - & - & - \\
Vibrio alginolyticus & - & - & - & - & - & - & - & - \\
Vibrio parahaemolyticus & - & - & - & - & - & + & - & - \\
Yersinia & - & + & - & - & - & - & - & - \\
Proteus & + & - & + & + & + & - & - & + \\
Providencia & + & + & - & + & - & - & - & + \\
Citrobacter & - & - & + & + & - & + & - & - \\
Edwardsiella & - & - & - & - & + & + & - & + \\
Pseudomonas aeroginosa & - & - & - & + & - & - & - & + \\
Escherichia coli & + & + & + & + & + & + & + & + \\
\hline
\end{tabular}


Water Quality Indicator Bacteria In Bengawan Solo And Porong Rivers And Their Estuaries (Soeminarti S. Thayib, et.al.)

Water Quality Indicator Bacteria in Bengawan Solo

\section{REFERENCES}

CABELLI, V. 1978. New standards for enteric bacteria. In : Water pollution microbiology (RALPH MITCHELL ed). John Wiley Sons, Canada : 233-271.

CARNEY, J.F; G.E. CARTY and R.R. COLWELL 1975. Seasonal occurrences and distribution of microbiol indicator and pathogens in the Rode River of Chesapeake Bay. Appl. Microbiol 30 : 771 - 789.

GRUNNET, K. 1975. Salmonella in sewage and receiving waters. Fadl' Forlag Copenhagen Arhus. Odense : 107 pp.

RHEINHEIMER,G. 1970. Microbiologie. Kieler Meeresforsch. 26 : 150 - 174.

RHEINHEIMER, G. 1980. Aquatic Microbiology. John Wiley \& Sons, Chichester, New York, Brisbane, Toronto : $235 \mathrm{pp}$.

THAYIB, S.S. and F. SUHADI 1977. Preliminary study on the distribution of the aerobic heterotrophic bacteria and the microbial indicators in Jakarta Bay. Mar. Res. in Indonesia $20: 87-97$.

THAYIB, S.S. and F. SUHADI 1980. The distribution and occurrences of microbial indicators in the Strait of Bangka and Jakarta Bay waters. In : "Tropical Ecology and Development" (J.I. FURTADO ed.) : 1163 - 1168. The International Society of Tropical Ecology, Kuala Lumpur.

WORLD HEALTH ORGANIZATION 1977. Guidelines for health related monitoring of coastal water quality. WHO, Regional Office fur Europe, Copenhagen : 165 pp. 